\title{
Recurrent miscarriage
}

\author{
Andrew W Horne, Claire I Alexander
}

\begin{abstract}
Recurrent miscarriage, the occurrence of three consecutive first-trimester losses of pregnancy, affects $1 \%$ of women. The purported causes of recurrent miscarriage include chromosomal abnormalities, thrombophilia, metabolic disorders, anatomical causes and immune factors. At present, the only recommended investigations are testing for lupus anticoagulant and anticardiolipin antibody levels (to diagnose antiphospholipid syndrome, an acquired thrombophilia) and the karyotyping of both parents for chromosomal abnormalities. Women with antiphospholipid syndrome should be offered treatment with aspirin and low molecular weight heparin. Couples with chromosomal abnormalities should be referred to a clinical geneticist with whom the options of prenatal diagnosis, pre-implantation genetic diagnosis, donor gametes and adoption in subsequent pregnancies should be discussed. Couples with unexplained recurrent miscarriage should be offered appropriate emotional support and reassurance that they have a good prognosis for future pregnancies.
\end{abstract}

J Fam Plann Reprod Health Care 2005; 31(2): 103-107 (Accepted 25 January 2005)

\section{Key message points}

- Couples with recurrent miscarriage should be offered karyotyping and be referred to a clinical geneticist for genetic counselling if they have a chromosomal abnormality.

- Screening for antiphospholipid syndrome in women with recurrent miscarriage is recommended and women with antiphospholipid syndrome should be offered treatment with aspirin and low molecular weight heparin.

- Supportive care alone is of considerable benefit for cases of unexplained recurrent miscarriage.

\section{Background}

Recurrent miscarriage affects $1 \%$ of all women. ${ }^{1}$ It is defined as the occurrence of three consecutive firsttrimester losses of pregnancy. Although pregnancy loss is common (affecting 10-15\% of pregnancies), this incidence is greater than that expected by chance alone $(0.34 \%){ }^{2}$ It is a very frustrating condition for both the couple and the clinician, because it is rare to find a clear-cut reason for the repeated failure to sustain a pregnancy and, as a consequence, the prospect of a satisfactory treatment. Maternal age and success of previous pregnancies are two independent risk factors for miscarriage. Older mothers have fewer good quality oocytes than younger mothers thus increasing the likelihood of chromosomal abnormalities leading to miscarriage. ${ }^{3-5}$ The risk of further miscarriage

Simpson Centre for Reproductive Health, Royal Infirmary of Edinburgh, Edinburgh, UK

Andrew W Horne, PhD, MRCOG, Specialist Registrar

Claire I Alexander, MPhil, MRCOG, Consultant

Correspondence to: Dr Andrew Horne, Simpson Centre for Reproductive Health, Royal Infirmary of Edinburgh, 51 Little France Crescent, Edinburgh EH16 4SA, UK.

Tel: +44 (0) 131536 1000. E-mail: awhorne@hotmail.com increases to approximately $50 \%$ for women with three or more losses without a liveborn infant.6,7 The purported causes of recurrent miscarriage include chromosomal anomalies, thrombophilia, metabolic disorders, anatomical causes and immune factors.

\section{Parental chromosomal anomalies}

In approximately $3-5 \%$ of couples with recurrent miscarriage one of the partners is affected by a chromosomal translocation (as opposed to $0.2 \%$ in the normal population), the wife being affected twice as frequently as the husband. ${ }^{8}$ This is usually a balanced reciprocal or Robertsonian translocation ${ }^{9,10}$ and results in an unbalanced translocation in the fetus.

Couples should be offered karyotyping and referred to a clinical geneticist for genetic counselling if they have a chromosomal abnormality. The options of prenatal diagnosis, preimplantation genetic diagnosis (PGD), donor gametes, and adoption in subsequent pregnancies should be discussed.

\section{Fetal chromosomal anomalies}

Several studies have suggested that fetal chromosomal anomalies account for a large proportion of recurrent miscarriages. Indeed, it has been suggested that recurrent miscarriage is the result of the failure of the prevention of 'poor quality' embryos implanting, allowing embryos that are destined to fail to implant and present clinically as recurrent miscarriage. Thus, recurrent miscarriage could be thought of as a failure of nature's quality control. ${ }^{11}$ PGD has shown that women with recurrent miscarriage produce more aneuploid embryos than normal women. ${ }^{12-15}$ In one study, when PGD was used to discard karyotypically abnormal embryos, the miscarriage rate after in vitro fertilisation (IVF) decreased. ${ }^{16}$ Interestingly, the majority of these aneuploid embryos were shown to be as a result of maternal oocyte abnormalities, 17,18 although other studies have also suggested an association between sperm chromosomal anomalies (and sperm DNA damage) and recurrent miscarriage. $19-21$ However, the question remains as to why couples who recurrently produce abnormal embryos do not present with infertility because of recurrent subclinical pregnancy loss.

At present, karyotyping the products of conception following miscarriage may be viewed in some hospitals as an unnecessary luxury. However, in the absence of karyotyping, it is assumed that women who repeatedly miscarry are losing normal pregnancies. Data detailed above have shown this is unlikely to be the case. Women with recurrent miscarriage are given expensive, intensive treatment (such as heparin) to prevent miscarriage. Such treatment is not appropriate if the losses are due to karyotypic abnormalities. Therefore, obtaining a karyotype after several pregnancy losses is important.

Antiphospholipid syndrome (acquired thrombophilia) The diagnosis of antiphospholipid syndrome is made when an adverse pregnancy outcome (such as recurrent miscarriage) or vascular thrombosis is associated with the presence of antiphospholipid antibodies (aPL). To diagnose the antiphospholipid syndrome, it is mandatory that the patient should have two positive tests at least 6 weeks apart 
for either lupus anticoagulant or anticardiolipin antibodies of immunoglobulin $\mathrm{G}$ (IgG) and/or IgM class present in medium or high titre. Antiphospholipid antibodies are present in $15 \%$ of women with recurrent miscarriage (compared to $2 \%$ in the low-risk population). ${ }^{22}$ Although a causal relationship between the antiphospholipid syndrome and recurrent miscarriage has not been identified, several therapeutic trials with low-dose aspirin, heparin and steroids have been conducted. ${ }^{23-26}$ A recent review concluded that a combination of aspirin and low molecular weight heparin therapy might reduce pregnancy loss in women with aPL by $54 \% .27$ There is no evidence that steroids improve the live birth rate of women with recurrent miscarriage..$^{23,24}$

Live birth rate in women with recurrent miscarriage and aPL is significantly improved by treatment with a combination of aspirin and heparin. Screening for antiphospholipid syndrome in women with recurrent miscarriage is recommended.

\section{Hereditary thrombophilia}

There have been a number of small studies reporting a positive association between factor $\mathrm{V}$ Leiden (FVL) and recurrent miscarriage ${ }^{28-30}$ and three uncontrolled studies have suggested that heparin therapy may improve the live birth rate for women with FVL mutation. ${ }^{29,31,32}$ Further unpublished, randomised controlled studies have suggested that routine screening for FVL, and offering thromboprophylaxis for those with FVL mutation and recurrent miscarriage, may be justified (L. Regan, personal communication).

\section{Exaggerated haemostatic response}

It has been recently proposed that many cases of recurrent miscarriage are due to an exaggerated haemostatic response during pregnancy leading to thrombosis of the uteroplacental vasculature and subsequent fetal loss. ${ }^{33}$ In a large study, thromboelastography (a test of whole blood haemostasis) has shown that there is a subgroup of women with recurrent miscarriage who are in a prothrombotic state outside of pregnancy and at risk of future miscarriage. ${ }^{34}$

\section{Metabolic disorders}

Elevated levels of luteinising hormone (LH) and polycystic ovarian syndrome (PCOS) have been shown to be associated with miscarriage. ${ }^{10,35}$ However, the Cochrane Subfertility Review Group concluded that there was not enough evidence that prepregnancy suppression of high LH, among ovulatory women with recurrent miscarriage and polycystic ovaries who hypersecrete $\mathrm{LH}$, improves live birth rate. ${ }^{36,37}$ Furthermore, recent data actually refute the association between elevated LH levels and PCOS with poor pregnancy outcome. ${ }^{38-40}$ However, two studies have shown that androgen levels (independent of PCOS) in the follicular phase are higher in women who have recurrent miscarriage than in fertile controls. ${ }^{41,42}$ In vitro studies have suggested that androgens increase epidermal growth factor receptor concentration that in turn has an adverse effect on endometrial glandular cell function. ${ }^{43,44} \mathrm{~A}$ randomised controlled trial has reported that treatment with bromocriptine increased the percentage of successful pregnancies in women with a history of two or more miscarriages and hyperprolactinaemia. ${ }^{45}$ Nevertheless, there is no firm evidence to suggest that hyperprolactinaemia is associated with recurrent miscarriage. ${ }^{39}$ Insulin resistance and obesity have both been shown to be associated with recurrent miscarriage, ${ }^{46,47}$ and two small studies have also shown that metformin was found to decrease the incidence of spontaneous miscarriage. 48,49 However, there is no strong evidence to support an association between either diabetes or thyroid function and pregnancy loss. $39,42,50,51$

\section{Infective factors}

The role of infection in recurrent miscarriage is unclear. Whilst bacterial vaginosis is associated with late pregnancy loss, preterm labour and premature rupture of membranes, 52 its association with recurrent miscarriage is not known. However, a recent study has shown that bacterial vaginosis was associated with an increased risk of early miscarriage in women undergoing IVF treatment. ${ }^{53}$ Toxoplasmosis, rubella, cytomegalovirus, herpes $(\mathrm{TORCH})$ and listeria infections are not thought to be infective causes of miscarriage. ${ }^{54,55}$

TORCH and bacterial vaginosis screening are not helpful in the treatment of recurrent miscarriage.

\section{Uterine abnormalities}

It is difficult to assess the exact contribution that uterine anomalies make to recurrent pregnancy loss. Their reported prevalence and reproductive implications are contested. The most common congenital structural uterine anomaly associated with miscarriage, including diethylstilboestrol-related anomalies, is the septate uterus. ${ }^{56}$ It would appear that the septal endometrium shows defective development, indicative of a reduction in sensitivity to steroid hormones. 57 Of the acquired conditions, Asherman's syndrome is the best documented.58 In this condition, post-traumatic intrauterine adhesions partly, or completely, obliterate the uterine cavity. Successful division of the uterine adhesions is thought to restore the responsiveness of the endometrium to the sex steroid hormones. Pregnancy rates after hysteroscopic treatment of the intrauterine adhesions depend upon the degree of the initial problem, ${ }^{59}$ being $93 \%$ for mild and $57 \%$ for severe disease. The situation with respect to the fibroid uterus is less clear. It is not known whether the endometrium covering a submucous fibroid responds suboptimally to steroid hormones increasing the risk of pregnancy loss. However, there is some evidence that removal of submucous fibroids reduces miscarriage rates. ${ }^{60,61}$

The routine use of the hysterosalpingogram as a screening test for uterine anomalies is questionable.

\section{Endometrial causes}

Recurrent miscarriage may be associated with retarded endometrial development in the peri-implantation period or luteal phase defect (LPD). ${ }^{39}$ To our knowledge, only two studies have examined endometrial morphology in women with recurrent miscarriage 62,63 by taking precisely timed endometrial biopsy specimens in women in whom comprehensive investigations into the cause of recurrent miscarriage were conducted. The incidence of LPD in these two studies was reported as $17.4 \% 62$ and $29 \% .63$ It is possible that steroid receptor abnormalities may be an explanation for the observed abnormality. Delayed downregulation of the progesterone receptor (PR) was observed in timed endometrial biopsies from a small group of women with recurrent miscarriage. 39 However, no data so far exist differentiating the two isoforms of $\mathrm{PR}$, or examining the expression pattern of those of the oestrogen receptor. Also, no differences have been observed in androgen receptor expression in women with recurrent miscarriage. ${ }^{39}$ Furthermore, a review of 
hormonal treatments for LPD concluded that the benefits are uncertain. ${ }^{64}$ The measurement of glycodelin A (previously called PP14) in endometrial flushings has been used successfully to identify endometrial defects. ${ }^{65,66}$ The concentration of glycodelin $\mathrm{A}$ was significantly lower in the flushings from the recurrent miscarriage patients than in those from fertile controls on both day $\mathrm{LH}+10$ and $\mathrm{LH}+12$. MUC1 is an anti-adhesion molecule that is thought to contribute to the barrier function of the endometrial surface, which resists implantation except during a specific time window in the mid-secretory phase ${ }^{67,68}$ Expression of the endometrial protein MUC1 was found to be lower in the endometrium of women suffering from recurrent miscarriage than controls, ${ }^{69}$ suggesting that epithelial function may be compromised in some cases of recurrent miscarriage.

The treatment of endometrial defects is controversial. The earlier studies that observed an association between LPD and recurrent miscarriage led to the development of a number of unsuccessful hormonal treatments. In particular, the use of progesterone supplementation has not been shown to be of benefit. More recent studies that have identified specific molecular abnormalities have contributed to our overall understanding of the aetiology of recurrent miscarriage, but not to its management.

\section{Immune factors}

For many years it has been speculated that a defect in the maternal immune response to the semi-allogenic fetal graft could be involved in the mechanism of recurrent miscarriage. Immunisation of women with recurrent miscarriage with paternal or third-party leukocytes, or with repeated boluses of gammaglobulins, prior to a next pregnancy has been tried in an attempt to replicate the paradoxical opposing parental histocompatibility that seems to be necessary for maintaining pregnancy. However, a Cochrane systematic review has shown that the use of immunotherapy in women with recurrent miscarriage provides no significant benefit. ${ }^{70}$ Nevertheless, in the research field a number of observations have been made suggesting other immunological factors may be important in the aetiology of the condition. Autoantibodies are more common in patients with recurrent miscarriage. The most common are antiphospholipid (14\%) and antinuclear antibodies (7\%), although the significance of the latter is uncertain. ${ }^{71,72}$ Thyroid antibodies have also been shown to be increased in women with recurrent miscarriage in a number of studies. ${ }^{73,74}$ Their prognostic value is, however, doubtful. ${ }^{75}$ Several studies have reported alterations in the cellular immune response. The peripheral blood of women with recurrent miscarriage has been shown to have a higher proportion of activated natural killer cells in vivo than control subjects. ${ }^{76}$ Women with recurrent miscarriage whose subsequent pregnancies progressed to term delivery have been shown to have a lower natural killer cell number and Th1:Th2 cytokine ratio $(\mathrm{Th}=\mathrm{T}$ helper cell $)$ than women whose pregnancies miscarried again. ${ }^{77,78}$ Endometrial leukaemia inhibitory factor (LIF) is known to be essential for implantation in the mouse. ${ }^{79}$ Decreased expression of LIF and interleukin 6 (IL-6), a related T helper cell cytokine, has also been demonstrated in some women who suffer recurrent miscarriage ${ }^{80,81}$ Endometrial leukocyte populations such as stromal CD56+ uterine natural killer cells, and various other stromal leukocyte populations, have been examined in recurrent miscarriage, and found to be of prognostic value. It has been demonstrated that the endometrium of non-pregnant women with a history of recurrent miscarriage contains an increased proportion of CD16+ CD56dim uterine natural killer cells compared with normal fertile women in whom CD16- CD56bright uterine natural killer cells predominate. ${ }^{82}$ Increased numbers of CD56+ uterine natural killer cells were also found in the preimplantation endometrium of recurrent miscarriage patients compared with controls. ${ }^{11,83}$ Furthermore, there were more CD56+ leukocytes in the endometrium of patients who subsequently miscarried than in those who had live births. ${ }^{83}$ There is no general agreement as to the function of uterine CD56+ uterine natural killer cells in relation to pregnancy, however these observations suggest that they might facilitate embryo implantation, including those embryos with abnormal karyotypes, leading to the clinical presentation of recurrent miscarriage.

At present, the administration of cells or cellular products in humans for the treatment of recurrent miscarriage should only be performed in the context of research.

\section{Cervical weakness}

Cervical weakness can cause pregnancy loss in the second trimester but there is no single truly diagnostic test for cervical weakness. ${ }^{84,85}$ The Medical Research Council/ Royal College of Obstetricians and Gynaecologists trial of elective cervical cerclage reported a small decrease in preterm birth and delivery of very-low birthweight babies, but the benefit was most marked in women with three or more second-trimester miscarriages or preterm births. However, there was no significant improvement in perinatal survival. 86

Due to the risks of surgery, cervical cerclage should only be offered to carefully selected women with previous second-trimester pregnancy loss.

\section{Lifestyle factors}

Smoking and alcohol consumption are both associated with miscarriage ${ }^{87,88}$ Excessive coffee consumption may also increase the risk of miscarriage ${ }^{89,90}$ It seems sensible to strongly recommend a healthy lifestyle and give advice regarding smoking, alcohol and caffeine consumption to couples with recurrent miscarriage.

\section{Unexplained factors}

In up to $50 \%$ of cases of recurrent miscarriage no causative factor is found. ${ }^{10,91}$ Fortunately, these women have an excellent prognosis for future pregnancy outcome if offered supportive care alone from a dedicated early pregnancy support clinic. ${ }^{92-94}$

\section{Conclusions}

According to the definition of recurrent miscarriage, investigation and treatment (if appropriate) should only start after three consecutive losses. Currently, the only recommended investigations are testing for lupus anticoagulant and anticardiolipin antibody levels and karyotyping both parents. Women with antiphospholipid syndrome should be offered treatment with aspirin and low molecular weight heparin. Couples with chromosomal anomalies should be referred to a clinical geneticist with whom the options of prenatal diagnosis, PGD, donor gametes and adoption in subsequent pregnancies should be discussed. Couples with unexplained recurrent miscarriage should be offered appropriate emotional support and reassurance that they have a good prognosis for future pregnancies. Hopefully, continued investigation to further our understanding of the pathophysiology of recurrent miscarriage will lead to more successful treatment and improved outcome in women with recurrent miscarriage. 


\section{Acknowledgemen}

The authors gratefully acknowledge Professor Lesley Regan for her help and advice in the preparation of this manuscript.

\section{Statements on funding and competing interests}

Funding. None identified.

Competing interests. None identified.

\section{References}

1 Stirrat GM. Recurrent miscarriage. Lancet 1990; 336: 673-675.

2 Alberman E. The epidemiology of repeated abortion. In: Beard RW, Sharp F (eds), Early Pregnancy Loss: Mechanisms and Treatment. London, UK: RCOG Press, 1988; 9-17.

3 Abdalla HI, Burton G, Kirkland A, Johnson MR, Leonard T, Brooks AA, et al. Age, pregnancy and miscarriage: uterine versus ovarian factors. Hum Reprod 1993; 8: 1512-1517.

4 Munne S, Alikani M, Tomkin G, Grifo J, Cohen J. Embryo morphology, developmental rates, and maternal age are correlated with chromosome abnormalities. Fertil Steril 1995; 64: 382-391.

5 Nybo Andersen AM, Wohlfahrt J, Christens P, Olsen J, Melbye M. Maternal age and fetal loss: population based register linkage study. BMJ 2000; 320: 1708-1712.

6 Poland BJ, Miller JR, Jones DC, Trimble BK. Reproductive counseling in patients who have had a spontaneous abortion. Am J Obstet Gynecol 1977; 127: 685-691.

7 Regan L, Braude PR, Trembath PL. Influence of past reproductive performance on risk of spontaneous abortion. BMJ 1989; 299: 541-545.

8 Stenchever MA, Droegemueller W, Herbst AL, Mishell DR (eds). Spontaneous and recurrent abortion. In: Comprehensive Gynecology (4th edn). St Louis, MO: CV Mosby, 2001; 280-299.

9 De Braekeleer M, Dao TN. Cytogenetic studies in couples experiencing repeated pregnancy losses. Hum Reprod 1990; 5: 519-528.

10 Clifford K, Rai R, Watson H, Regan L. An informative protocol for the investigation of recurrent miscarriage: preliminary experience of 500 consecutive cases. Hum Reprod. 1994; 9: 1328-1332.

11 Quenby S, Bates M, Doig T, Brewster J, Lewis-Jones DI, Johnson PM, et al. Pre-implantation endometrial leukocytes in women with recurrent miscarriage. Hum Reprod 1999; 14: 2386-2391.

12 Simon C, Rubio C, Vidal F, Gimenez C, Moreno C, Parrilla JJ, et al. Increased chromosome abnormalities in human preimplantation embryos after in-vitro fertilization in patients with recurren miscarriage. Reprod Fertil Dev 1998; 10: 87-92.

13 Vidal F, Gimenez C, Rubio C, Simon C, Pellicer A, Santalo J, et al. FISH preimplantation diagnosis of chromosome aneuploidy in recurrent pregnancy wastage. J Assist Reprod Genet 1998; 15: 310-313.

14 Pellicer A, Rubio C, Vidal F, Minguez Y, Gimenez C, Egozcue J, et al. In vitro fertilization plus preimplantation genetic diagnosis in patients with recurrent miscarriage: an analysis of chromosome abnormalities in human preimplantation embryos. Fertil Steril 1999; 71: 1033-1039.

15 Gianaroli L, Magli MC, Ferraretti AP. The in vivo and in vitro efficiency and efficacy of PGD for aneuploidy. Mol Cell Endocrinol 2001; 183(Suppl. 1): 13-18

16 Munne S, Magli C, Cohen J, Morton P, Sadowy S, Gianaroli L, et al. Positive outcome after preimplantation diagnosis of aneuploidy in human embryos. Hum Reprod 1999; 14: 2191-2199.

17 Cobo A, Rubio C, Gerli S, Ruiz A, Pellicer A, Remohi J. Use of fluorescence in situ hybridization to assess the chromosomal status of embryos obtained from cryopreserved oocytes. Fertil Steril 2001; 75: $354-360$

18 Robinson WP, Beever C, Brown CJ, Stephenson MD. Skewed X inactivation and recurrent spontaneous abortion. Semin Reprod Med 2001; 19: 175-181

19 Giorlandino C, Calugi G, Iaconianni L, Santoro ML, Lippa A. Spermatozoa with chromosomal abnormalities may result in a higher rate of recurrent abortion. Fertil Steril 1998; 3: 576-577.

20 Rubio C, Simon C, Blanco J, Vidal F, Minguez Y, Egozcue J, et al. Implications of sperm chromosome abnormalities in recurrent miscarriage. J Assist Reprod Genet 1999; 16: 253-258.

21 Egozcue S, Blanco J, Vendrell JM, Garcia F, Veiga A, Aran B, et al. Human male infertility: chromosome anomalies, meiotic disorders, abnormal spermatozoa and recurrent abortion. Hum Reprod Update 2000; 6: 93-105.

22 Rai RS, Regan L, Clifford K, Pickering W, Dave M, Mackie I, et al. Antiphospholipid antibodies and beta 2-glycoprotein-I in 500 women with recurrent miscarriage: results of a comprehensive screening approach. Hum Reprod 1995; 10: 2001-2005.

23 Cowchock FS, Reece EA, Balaban D, Branch DW, Plouffe L. Repeated fetal losses associated with antiphospholipid antibodies: a collaborative randomized trial comparing prednisone with low-dose heparin treatment. Am J Obstet Gynecol 1992; 166: 1318-1323.

24 Silver RK, MacGregor SN, Sholl JS, Hobart JM, Neerhof MG, Ragin
A. Comparative trial of prednisolone plus aspirin versus aspirin alone in the treatment of anticardiolipin antibody-positive obstetric patients. Am J Obstet Gynecol 1993; 169: 1411-1417.

25 Rai R, Cohen H, Dave M, Regan L. Randomised controlled trial of aspirin and aspirin plus heparin in pregnant women with recurrent miscarriage associated with phospholipid antibodies (or antiphospholipid antibodies) $B M J$ 1997; 314: 253-257.

26 Farquharson RG, Quenby S, Greaves M. Antiphospholipid syndrome in pregnancy: a randomized, controlled trial of treatment. Obstet Gynecol 2002; 100: 408-413.

27 Empson M, Lassere M, Craig JC, Scott JR. Recurrent pregnancy loss with antiphospholipid antibody: a systematic review of therapeutic trials. Obstet Gynecol 2002; 99: 135-144.

28 Grandone E, Margaglione M, Colaizzo D, d'Addedda M, Cappucci $\mathrm{G}$, Vecchione $\mathrm{G}$, et al. Factor V Leiden is associated with repeated and recurrent unexplained fetal losses. Thromb Haemost 1997; 77: $822-824$

29 Younis JS, Brenner B, Ohel G, Tal J, Lanir N, Ben-Ami M. Activated protein $\mathrm{C}$ resistance and factor $\mathrm{V}$ Leiden mutation can be associated with first- as well as second-trimester recurrent pregnancy loss. Am J Reprod Immunol 2000; 43: 31-35.

30 Rai R, Shlebak A, Cohen H, Backos M, Holmes Z, Marriott K, et al. Factor V Leiden and acquired activated protein $\mathrm{C}$ resistance among 1000 women with recurrent miscarriage. Hum Reprod 2001; 5: 961-965.

31 Brenner B, Hoffman R, Blumenfeld Z, Weiner Z, Younis JS . Gestational outcome in thrombophilic women with recurrent pregnancy loss treated by enoxaparin. Thromb Haemost 2000; 83: 693-697.

32 Ogueh O, Chen MF, Spurll G, Benjamin A. Outcome of pregnancy in women with hereditary thrombophilia. Int J Gynaecol Obstet 2001; 74: $247-253$.

33 Rai R. Is miscarriage a coagulopathy? Curr Opin Obstet Gynecol 2003; 15: 265-268

34 Rai R, Tuddenham E, Backos M, Jivraj S, El'Gaddal S, Choy S, et al. Thromboelastography, whole-blood haemostasis and recurrent miscarriage. Hum Reprod 2003; 18: 2540-2543.

35 Regan L, Owen EJ, Jacobs HS. Hypersecretion of luteinising hormone, infertility, and miscarriage Lancet 1990; 336: 1141-1144.

36 Clifford K, Rai R, Watson H, Franks S, Regan L. Does suppressing luteinising hormone secretion reduce the miscarriage rate? Results of a randomised controlled trial. BMJ 1996; 312: 1508-1511.

37 Hughes E, Collins J, Vandekerckhove P. Ovulation induction with urinary follicle stimulating hormone versus human menopausal gonadotropin for clomiphene-resistant polycystic ovary syndrome. Cochrane Database Syst Rev 2000; 2: CD000087.

38 Rai R, Backos M, Rushworth F, Regan L. Polycystic ovaries and recurrent miscarriage - a reappraisal. Hum Reprod 2000; 15: 612-615.

39 Li TC, Spuijbroek MD, Tuckerman E, Anstie B, Loxley M, Laird S. Endocrinological and endometrial factors in recurrent miscarriage. $\mathrm{Br}$ J Obstet Gynaecol 2000; 107: 1471-1479.

40 Nardo LG, Rai R, Backos M, El-Gaddal S, Regan L. High serum luteinizing hormone and testosterone concentrations do not predict pregnancy outcome in women with recurrent miscarriage. Fertil Steril 2002; 77: 348-352.

41 Okon MA, Laird SM, Tuckerman EM, Li TC. Serum androgen levels in women who have recurrent miscarriages and their correlation with markers of endometrial function. Fertil Steril 1998; 69: 682-690.

42 Bussen S, Sutterlin M, Steck T. Endocrine abnormalities during the follicular phase in women with recurrent spontaneous abortion. Hum Reprod 1999; 14: 18-20.

43 Watson H, Franks S, Bonney RC. Regulation of epidermal growth factor receptor by androgens in human endometrial cells in culture. Hum Reprod 1998; 13: 2585-2591.

44 Tuckerman EM, Okon MA, Li T, Laird SM. Do androgens have a direct effect on endometrial function? An in vitro study. Fertil Steril 2000; 74: 771-779

45 Dlugi AM. Hyperprolactinemic recurrent spontaneous pregnancy loss: a true clinical entity or a spurious finding? Fertil Steril 1998; 70: 253-255

46 Wang JX, Davies MJ, Norman RJ. Obesity increases the risk of spontaneous abortion during infertility treatment. Obes Res 2002; 10: $551-554$

47 Craig LB, Ke RW, Kutteh WH. Increased prevalence of insulin resistance in women with a history of recurrent pregnancy loss. Fertil Steril 2002; 78: 487-490.

48 Jakubowicz DJ, Iuorno MJ, Jakubowicz S, Roberts KA, Nestler JE. Effects of metformin on early pregnancy loss in the polycystic ovary syndrome. J Clin Endocrinol Metab 2002; 87: 524-529.

49 Glueck CJ, Wang P, Goldenberg N, Sieve-Smith L. Pregnancy outcomes among women with polycystic ovary syndrome treated with metformin. Hum Reprod 2002; 17: 2858-2864.

50 Mills JL, Simpson JL, Driscoll SG, Jovanovic-Peterson L, Van Allen $\mathrm{M}$, Aarons $\mathrm{JH}$, et al. Incidence of spontaneous abortion among 
normal women and insulin-dependent diabetic women whose pregnancies were identified within 21 days of conception. $N$ Engl J Med 1988; 319: 1617-1623.

51 Abalovich M, Gutierrez S, Alcaraz G, Maccallini G, Garcia A, Levalle $\mathrm{O}$. Overt and subclinical hypothyroidism complicating pregnancy. Thyroid 2002; 12: 63-68

52 Hay PE, Lamont RF, Taylor-Robinson D, Morgan DJ, Ison C, Pearson J. Abnormal bacterial colonisation of the genital tract and subsequent preterm delivery and late miscarriage. BMJ 1994; 308: 295-298.

53 Ralph SG, Rutherford AJ, Wilson JD. Influence of bacterial vaginosis on conception and miscarriage in the first trimester: cohort study. BMJ 1999; 319: 220-223.

54 Summers PR. Microbiology relevant to recurrent miscarriage. Clin Obstet Gynecol 1994; 37: 722-729.

55 Regan L, Jivraj S. Infection and pregnancy loss. In: Maclean A, Regan L, Carrington D (eds), Infection and Pregnancy. London, UK: RCOG Press, 2001; 291-304.

56 Homer HA, Li TC, Cooke ID. The septate uterus: a review of management and reproductive outcome. Fertil Steril 2000; 73: 1-14.

57 Fedele L, Bianchi S, Marchini M, Franchi D, Tozzi L, Dorta M. Ultrastructural aspects of endometrium in infertile women with septate uterus. Fertil Steril 1996; 65: 750-752.

58 Asherman JG. Traumatic intra-uterine adhesions. J Obstet Gynaecol Br Emp 1950; 57: 892-896.

59 Valle RF, Sciarra JJ. Intrauterine adhesions: hysteroscopic diagnosis, classification, treatment, and reproductive outcome. Am J Obstet Gynecol 1988; 158: 1459-1470.

$60 \mathrm{Li} \mathrm{TC}$, Mortimer R, Cooke ID. Myomectomy: a retrospective study to examine reproductive performance before and after surgery. Hum Reprod 1999; 14: 1735-1740.

61 Bajekal N, Li TC. Fibroids, infertility and pregnancy wastage. Hum Reprod Update 2000; 6: 614-620.

62 Tulppala M, Bjorses UM, Stenman UH, Wahlstrom T, Ylikorkala O. Luteal phase defect in habitual abortion: progesterone in saliva. Fertil Steril 1991; 56: 41-44.

$63 \mathrm{Li} \mathrm{TC}$. Guides for practitioners. Recurrent miscarriage: principles of management. Hum Reprod 1998; 13: 478-482.

64 Karamardian LM, Grimes DA. Luteal phase deficiency: effect of treatment on pregnancy rates. Am J Obstet Gynecol 1992; 167: 1391-1398.

65 Dalton CF, Laird SM, Estdale SE, Saravelos HG, Li TC. Endometrial protein PP14 and CA-125 in recurrent miscarriage patients; correlation with pregnancy outcome. Hum Reprod 1998; 13: 3197-3202.

66 Dalton CF, Laird SM, Serle E, Saravelos H, Warren MA, Li TC, et al. The measurement of CA 125 and placental protein 14 in uterine flushings in women with recurrent miscarriage; relation to endometrial morphology. Hum Reprod 1995; 10: 2680-2684.

67 Horne AW, White JO, Lalani el-N. Adhesion molecules and the normal endometrium. Br J Obstet Gynaecol 2002; 109: 610-617.

68 Horne AW, White JO, Lalani EN. The endometrium and embryo implantation. A receptive endometrium depends on more than hormonal influences. BMJ 2000; 321: 1301-1302.

69 Aplin JD, Hey NA, Li TC. MUC1 as a cell surface and secretory component of endometrial epithelium: reduced levels in recurrent miscarriage. Am J Reprod Immunol 1996; 35: 261-266.

70 Scott JR. Immunotherapy for recurrent miscarriage. Cochrane Database Syst Rev 2000; 2: CD000112.

71 Lin QD. Investigation of the association between autoantibodies and recurrent abortions. Zhonghua Fu Chan Ke Za Zhi 1993; 28: 674-677, 702.

72 Tulppala M, Palosuo T, Ramsay T, Miettinen A, Salonen R, Ylikorkala O. A prospective study of 63 couples with a history of recurrent spontaneous abortion: contributing factors and outcome of subsequent pregnancies. Hum Reprod 1993; 8: 764-770.

73 Pratt DE, Kaberlein G, Dudkiewicz A, Karande V, Gleicher N. The association of antithyroid antibodies in euthyroid nonpregnant women with recurrent first trimester abortions in the next pregnancy. Fertil Steril 1993; 60: 1001-1005.

74 Bussen S, Steck T. Thyroid autoantibodies in euthyroid non-pregnan women with recurrent spontaneous abortions. Hum Reprod 1995; 10: 2938-2940.
75 Rushworth FH, Backos M, Rai R, Chilcott IT, Baxter N, Regan L. Prospective pregnancy outcome in untreated recurrent miscarriers with thyroid autoantibodies. Hum Reprod 2000; 15: 1637-1639.

76 Ntrivalas EI, Kwak-Kim JY, Gilman-Sachs A, Chung-Bang H, Ng $\mathrm{SC}$, Beaman KD, et al. Status of peripheral blood natural killer cells in women with recurrent spontaneous abortions and infertility of unknown aetiology. Hum Reprod 2001; 16: 855-861.

77 Emmer PM, Nelen WL, Steegers EA, Hendriks JC, Veerhoek M, Joosten I. Peripheral natural killer cytotoxicity and CD56(pos)CD16(pos) cells increase during early pregnancy in women with a history of recurrent spontaneous abortion. Hum Reprod 2000; 15: 1163-1169.

78 Makhseed M, Raghupathy R, Azizieh F, Omu A, Al-Shamali E, Ashkanani L. Th1 and Th2 cytokine profiles in recurrent aborters with successful pregnancy and with subsequent abortions. Hum Reprod 2001; 16: 2219-2226.

79 Stewart CL, Kaspar P, Brunet LJ, Bhatt H, Gadi I, Kontgen F, et al. Blastocyst implantation depends on maternal expression of leukaemia inhibitory factor. Nature 1992; 359: 76-79.

80 Lim KJ, Odukoya OA, Ajjan RA, Li TC, Weetman AP, Cooke ID. The role of T-helper cytokines in human reproduction. Fertil Steril 2000; 73: $136-142$

81 von Wolff M, Thaler CJ, Strowitzki T, Broome J, Stolz W, Tabibzadeh $\mathrm{S}$. Regulated expression of cytokines in human endometrium throughout the menstrual cycle: dysregulation in habitual abortion. Mol Hum Reprod 2000; 6: 627-634.

82 Lachapelle MH, Miron P, Hemmings R, Roy DC. Endometrial T, B, and NK cells in patients with recurrent spontaneous abortion. Altered profile and pregnancy outcome. J Immunol 1996; 156: 4027-4034.

83 Clifford K, Flanagan AM, Regan L. Endometrial CD56+ natural killer cells in women with recurrent miscarriage: a histomorphometric study. Hum Reprod 1999; 14: 2727-2730.

84 Anthony GS, Walker RG, Cameron AD, Price JL, Walker JJ, Calder AA. Transabdominal cervico-isthmic cerclage in the management of cervical incompetence. Eur J Obstet Gynecol Reprod Biol 1997; 72: 127-130.

85 Althuisius SM, Dekker GA, Hummel P, Bekedam DJ, van Geijn HP. Final results of the Cervical Incompetence Prevention Randomized Cerclage Trial (CIPRACT): therapeutic cerclage with bed rest versus bed rest alone. Am J Obstet Gynecol 2001; 185: 1106-1112.

$86 \mathrm{MRC} / \mathrm{RCOG}$ Working Party on Cervical Cerclage. Final report of the Medical Research Council/Royal College of Obstetricians and Gynaecologists multicentre randomised trial of cervical cerclage. $\mathrm{Br}$ J Obstet Gynaecol 1993; 100: 516-523.

87 Dominguez-Rojas V, de Juanes-Pardo JR, Astasio-Arbiza P, OrtegaMolina P, Gordillo-Florencio E. Spontaneous abortion in a hospital population: are tobacco and coffee intake risk factors? Eur $J$ Epidemiol 1994; 10: 665-658.

88 Florey CD. EUROMAC. A European concerted action: maternal alcohol consumption and its relation to the outcome of pregnancy and child development at 18 months. Int J Epidemiol 1992; 21(Suppl. 1): 38-39.

89 Parazzini F, Chatenoud L, Di Cintio E, Mezzopane R, Surace M, Zanconato $\mathrm{G}$, et al. Coffee consumption and risk of hospitalized miscarriage before 12 weeks of gestation. Hum Reprod 1998; 13: 2286-2291.

90 Rasch V. Cigarette, alcohol, and caffeine consumption: risk factors for spontaneous abortion. Acta Obstet Gynecol Scand 2003; 82: 182-188.

91 Katz VL, Kuller JA. Recurrent miscarriage. Am J Perinatol 1994; 11: 386-397.

92 Stray-Pedersen B, Stray-Pedersen S. Etiologic factors and subsequent reproductive performance in 195 couples with a prior history of habitual abortion. Am J Obstet Gynecol 1984; 148: 140-146.

93 Clifford K, Rai R, Regan L. Future pregnancy outcome in unexplained recurrent first trimester miscarriage. Hum Reprod 1997; 12: $387-389$.

94 Brigham SA, Conlon C, Farquharson RG. A longitudinal study of pregnancy outcome following idiopathic recurrent miscarriage. Hum Reprod 1999; 14: 2868-2871.

\section{LETTERS TO THE EDITOR}

Letters to the Editor are welcome and generally should not exceed 600 words or cite more than five references. For comments on material published in the most recent issue of the Journal, correspondence should be received within 4 weeks of dispatch of that Journal to be in time for inclusion in the next issue. When submitting letters correspondents should include their job title, a maximum of two qualifications and their address(es). A statement on competing interests should also be submitted for all letters. Letters may be submitted to the Editor or the Journal Editorial Office (details on page 89). 